\title{
ON THE HYDROID OF EUTIMA GRACILIS (FORBES AND GOODSIR)
}

\author{
By F. S. Russell, F.R.S.
}

Director of the Plymouth Laboratory

(Text-fig. I)

In July I938 I succeeded in rearing the hydroid of Eutima gracilis (Forbes and Goodsir) (also known as Saphenia gracilis) from adult medusae which liberated their eggs and sperm in finger-bowls of sea water. These hydroids were only in the primary polyp stage, and I withheld publication hoping to repeat the work
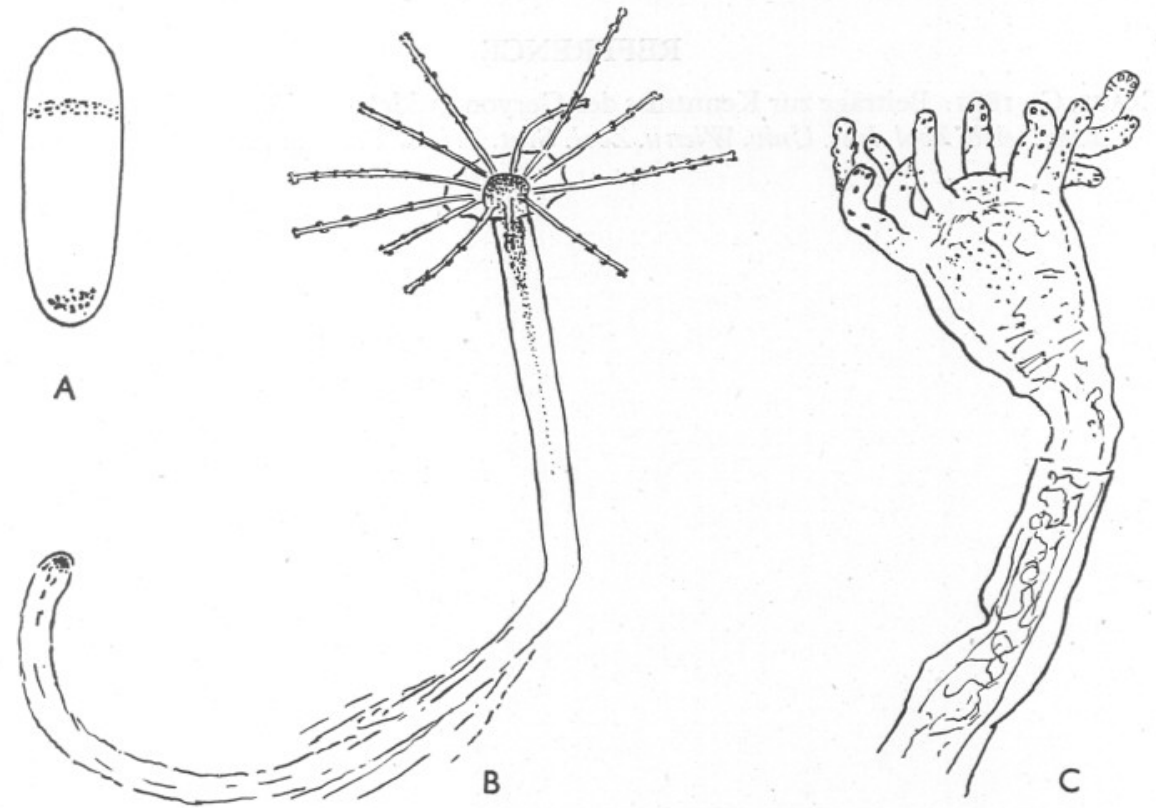

Fig. I. Eutima gracilis (Forbes and Goodsir), Plymouth, 22-23 July, 1938. A, planula, showing position of blue pigment granules; B, primary polyp, showing blue pigment granules at end of stolon and on hydranth at base of tentacles (alive); c, primary polyp, fully contracted (preserved).

later and perhaps rear the hydroid to a more advanced stage. As it is unlikely that I may now have the opportunity of doing this it seems worth while to publish a short account with figures of the polyp.

I have been unable to find any notes I may have made at the time, but the original drawings are available. The planula (Fig. IA), which is otherwise 
colourless, is characterized by a girdle of blue pigment granules near its anterior end and a mass of similar granules situated posteriorly. Fig. I B shows the primary polyp. The hydranth has a single whorl of twelve filiform tentacles whose bases are united by a membranous web. The hydrocaulus is simple and there is no hydrotheca; the hydranth is thus naked and unable to retract within the perisarc walls which at this stage are very delicate and transparent (see Fig. IC). At the original point of attachment of the stolon to the substratum the blue pigment granules are still present, and the hydranth itself has blue pigment just below the whorl of tentacles. Unfortunately, I am unable to give measurements.

In its two chief characteristics, namely the presence of a membranous web uniting the bases of the tentacles and the absence of a hydrotheca, this hydroid resembles Campanopsis which was described by Claus (I88I) as the hydroid of Octorchis gegenbauri Haeckel.

\section{REFERENCE}

Claus, C., I88I. Beiträge zur Kenntniss der Geryonopsiden- und Eucopiden-Entwicklung. Arb. Zool. Inst. Univ. Wien u. Zool. Stat. Triest, Tom. IV, Heft. I, pp. 89-I20. 